\title{
Inclusive practices in teaching students with dyslexia: Second language teachers' concerns, attitudes and self-efficacy beliefs on a massive open online learning course
}

\author{
Judit Kormos ${ }^{1}$ and Joanna Nijakowska ${ }^{2}$ \\ ${ }^{1}$ Department of Linguistics and English Language \\ Lancaster University \\ Lancaster, LA $14 \mathrm{YL}$ \\ United Kingdom \\ Email: j.kormos@lancaster.ac.uk \\ ${ }^{2}$ University of Łódź \\ Instytut Anglistyki \\ ul. Pomorska 171/173 \\ 90-236 Łódź \\ Poland \\ Email: jnijak@wp.pl
}

\section{Abstract}

In this study we investigated whether language teachers' self-confidence, self-efficacy and attitudes to using inclusive educational practices with dyslexic students differ before and after participation in a massive open online course (MOOC). An online questionnaire survey, before ( $n=1187)$ and after the course $(n=752)$, showed that the participants' post-course attitudes were more positive, their self-efficacy beliefs higher and their concerns lower than at the beginning of the course. Participants who completed more tasks on the course demonstrated increased post-course self-efficacy beliefs and those who posted more comments reported lower levels of worry about the implementation of inclusive language teaching practices. 


\section{Introduction}

Principles of inclusive education are based on the premise that people differ in the ways they learn, but everyone should have equal access to high-quality education and a supportive learning environment, including the context of learning additional languages. Inclusive education is strongly supported by the principles of social justice such as UNESCO's (2015) most recent Education for All monitoring report and the Convention on the Rights of Persons with Disabilities (United Nations General Assembly, 2006). Many countries of the world have ratified this convention and have passed legislation that aims to establish inclusive educational environments, where the individual needs of all students are successfully met (e.g. Individuals with Disabilities Act (2004) in the USA, the Equality Act (2010) in the UK and Disability Discrimination Act, 1992, in Australia).

Well-trained, aware and effective teachers are key to the success of inclusion. Responding to diverse learner needs in heterogeneous clasrooms, maximising the opportunities for participation in education for every student and restructuring mainstream schooling to include all children may, however, pose considerable challenges to teachers (Avramidis \& Norwitch, 2002; Jordan, Schwartz, \& McGhie-Richmond, 2009; Sharma \& Nuttall, 2016), especially language teachers, because they often lack appropriate training in inclusive practices (Nijakowska, 2014). Such questions as how to prepare teachers for working in inclusive classrooms, enhance their knowledge and skills, boost their self-efficacy beliefs and develop and sustain positive attitudes, as well as alleviate concerns, have been researched in multiple educational contexts. No previous studies, however, have focused on these issues as they relate to teachers of additional languages. Research in this area is required because a large number of studies provide evidence of the difficulties students with SpLDs experience in acquiring additional languages and the challenges of multilingual 
individuals with reading-related disabilities face in different levels of education (for a review see Kormos, 2016).

In this study we investigated language teachers' concerns, attitudes and self-efficacy beliefs regarding inclusive practices when teaching additional languages to students with dyslexia before and after participation in a MOOC on dyslexia and language teaching. In our research we also examined how previous training, self-reported level of knowledge about dyslexia, teaching context, level of education and teaching experience were related to preand post-course attitudes, self-efficacy beliefs and concerns about inclusion in language teaching. Finally, we explored how course participation, operationalised as the percentage of tasks and number of units completed as well as the number of comments and replies posted online, was related to post-course attitudes, self-efficacy beliefs and concerns about inclusive practices towards dyslexic language learners. This study contributes important new knowledge concerning the way these variables operate in the context of language teaching where pre- and in-service training in inclusive practices and specific learning difficulties is often unavailable (Nijakowska, 2014). The study is also novel in the field of teacher education as it took place in the previously under-researched context of a new mode of online learning, the MOOC.

\section{Review of literature}

Learners with specific learning difficulties (SpLDs), including those who have dyslexia, belong to a group of individuals with special educational needs (SEN). In addition to native language processing problems, students with SpLDs often experience difficulties in acquiring additional languages (see e.g. Kormos, 2016; Kormos \& Smith, 2011; Nijakowska, 2010; Peer \& Reid, 2016; Sparks, Ganschow, \& Pohlman, 1989; Sparks, Patton, Ganschow, Humbach, \& Javorsky, 2006; Schneider \& Crombie, 2003). These difficulties, which mostly 
affect the development of second language literacy skills and vocabulary knowledge, relate to the learning of additional languages in classroom contexts, as well as manifest themselves in multilingual contexts where children receive education in a language other than the one they use at home (e.g. Kormos, 2016; Martin, 2013). Language learners and multilinguals with SpLDs need to be taught using inclusive teaching practices and be provided with individualized support. Language teacher education schemes, however, offer scant initial training and continuous professional development opportunities in this respect (DysTEFL project - Needs analysis report, http://dystefl.eu/uploads/media/DysTEFLNeeds_analysis_report_01.pdf). Language teachers themselves also report that they lack sufficient background knowledge and understanding of the nature of dyslexia and the difficulties it causes in language learning and are not familiar with the instructional practices they should employ to fully include these learners (Nijakowska, 2014).

Previous studies have also revealed that a frequent cause of limited knowledge about inclusive practices and effective intervention programmes is insufficient and/or inadequate initial teacher training (e.g. Joshi, Binks, Graham, Dean, Smith, \& Boulware-Gooden, 2009; Goldfus, 2012). Relevant background knowledge and an appropriate understanding of the nature of learning difficulties are necessary in order to offer effective instruction to struggling readers (Bos, Mather, Dickson, Podhajski, \& Chard, 2001; Goldfus, 2012; Moats, 1994, 2009; Moats \& Foorman, 2003; Washburn, Joshi, \& Binks-Cantrell, 2011a, 2011b). Knowledge of successful reading intervention programmes and their underlying theoretical principles has been shown to serve as an important foundation for teachers' self-confidence (e.g. Brady et al., 2009; McCutchen \& Berninger, 1999; McCutchen, Abbott, Green, Beretvas, Cox, Potter \& Quiroga, 2002; McCutchen, Dawn, Cox, Sidman, Covill, \& Cunningham, 2002; McCutchen, Green, Abbott, \& Sanders, 2009; Podhajski, Mather, Nathan, \& Sammons, 2009). Previous studies have also highlighted the importance of 
professional training in upgrading teacher knowledge (e.g. Brady et al., 2009; Podhajski Mather, Nathan \& Sammons, 2009). Language teachers' lack of background knowledge, the unavailability of appropriate initial and continuing professional development and growing social and educational pressures relating to the implementation of inclusive practices may decrease teachers' self-efficacy beliefs, enhance their concerns and potentially lead to negative attitudes towards inclusion.

In their review of teacher attitudes towards inclusive education, Avramidis and Norwich (2002) suggest that teachers' attitudes towards inclusion are shaped by three factors: 1. child-related factors connected with the nature and severity of a disability; 2 : teacherrelated factors (e.g. gender, age, years of teaching experience, grade level, contact with disabled persons and personality factors); and 3. educational environment-related (context) factors, such as the availability of physical and human support. As regards child-related factors, teachers were found to be more willing to accept students with less severe disabilities for full-time placement in their mainstream classrooms and held more positive attitudes to the inclusion of children with physical and sensory impairments than students with learning and emotional-behavioural difficulties (Avramidis \& Norwich, 2002). At the level of teacherrelated factors, Forlin, Hattie and Douglas's (1996) study indicates that school principals who had minimal contact with students with SEN underestimated the stress for inclusion compared to experienced classroom teachers who held more realistic beliefs of the demands of successful inclusion. In a more recent study conducted in the context of primary education in Bangladesh, Ahmmed, Sharma and Deppeler (2012) found that perceived school support for inclusive teaching practices (operationalised as cooperation with other teachers, school administrators, parents of the students and the supply of teaching resources) as well as teacher-related variables such as contact and previous success in teaching students with SEN had a significant impact on teachers' attitudes towards inclusive education. 
Both pre- and in-service teachers tend to have concerns about inclusion. They are worried about the lack of time to appropriately plan, prepare and conduct lessons in inclusive classrooms, manage student behaviour in heterogeneous groups and the availability of resources (Forlin \& Cooper, 2013; Forlin \& Chambers, 2011; Horne \& Timmons, 2009). Teachers' concerns regarding their ability to implement inclusive practices are mitigated when classroom and school support services, such as resources, teaching materials, IT equipment, a restructured physical environment, learning support assistants, special teachers and speech therapists, are available (Avramidis \& Norwich, 2002). Research evidence also suggests that concerns tend to diminish when teacher attitudes become more positive and self-efficacy beliefs increase (Forlin, Sharma, \& Loreman, 2014; Sharma, Forlin, Loreman, \& Earle, 2006). Teachers' concerns about inclusion can also be considerably reduced by gaining knowledge and skills on teacher training courses (Sharma, Forlin, \& Loreman, 2008).

Teachers' self-efficacy beliefs are based on teachers' self-perceptions of their competence rather than their actual level of competence (Tschannen-Moran \& Woolfolk Hoy, 2007) and are defined as “(...) a judgment of his or her capabilities to bring about desired outcomes of student engagement and learning, even among those students who may be difficult or unmotivated" (Tschannen-Moran \& Woolfolk Hoy, 2001, p. 783). Selfefficacy beliefs can have a powerful effect on both teachers' and students' actions and thoughts (Bandura, 1977; Forlin et al., 2014; Malinen, Savolainen, \& Xu, 2012; Ozder, 2011; Sharma, Loreman, \& Forlin, 2012; Takahashi, 2011; Tschannen-Moran \& Woolfolk Hoy, 2001). Leyser, Zeiger and Romi (2011) demonstrated that years of preservice education, experience with children with special educational needs and training in inclusive education impact on the formation of self-efficacy beliefs of general and special education pre-service teachers. Malinen, Savolainen, Engelbrecht, Xu, Nel, Nel, and Tlale (2013) also found that 
one of the strongest predictors of self-efficacy beliefs relating to inclusive teaching was experience in teaching students with SEN.

A number of previous studies have investigated the impact of training on teachers' attitudes, concerns and self-efficacy beliefs relating to inclusive classroom practices. The results indicate that face-to-face teacher training courses bring positive results in terms of raising attitudes and self-efficacy beliefs and easing concerns (e.g. Carroll, Forlin, \& Jobling, 2003; Chao, Forlin, \& Ho, 2016; Campbell, Gilmore, \& Cuskelly, 2003; Forlin, et al., 2014; Lambe \& Bones, 2007; Peebles \& Mondaglio, 2014; Sharma et al., 2008; Sharma \& Nuttall, 2016; Sharma \& Sokal, 2015; Woodcock, Hemmings, \& Kay, 2012; Wilkins \& Nietfeld, 2004). Most of this research, however, has been conducted with pre-service teachers and the majority of studies have involved face-to-face training. Currently, little is known about the effectiveness of online teacher education programmes in terms of raising self-efficacy beliefs, enhancing attitudes and alleviating concerns about inclusion. In the domain of general teacher education, research findings suggest that there are no major differences in learning outcomes between face-to-face and online teacher training programmes (Jang, 2008; Kirtman, 2009). In the field of language teacher education, however, Kissau (2012) found that participants in an online teacher training course reported lower self-efficacy beliefs relating to language teaching than those in a face-to-face course. In a follow-up study, Kissau and Algozzine (2015) demonstrated that a hybrid mode of delivery was significantly more beneficial in terms of increasing self-efficacy beliefs than face-to-face and online courses.

Massive Open Online Courses are similar to distance education programmes in that they are delivered entirely online, yet they differ from them in that they are free of charge, open to anyone and are attended by large number of students. They usually include short video lecturers, readings, quizzes, automated tests, peer-assessment and online forums for interaction and discussion (Glance, Forsey \& Riley, 2013). There are two different types of 
MOOCs: one which follows more traditional design principles where the educator is the major source of knowledge and another where students form learning networks and jointly create knowledge (Guàrdia, Maina \& Sangrà, 2013). MOOCs are generally offered by international universities in collaboration with major providers such as Coursera, edX, Udacity and FutureLearn. Research on the effectiveness of MOOCs in terms of learning outcomes is scarce and has mostly been conducted in the area of physics teaching. These studies have found that MOOCs that cover the same instructional material as face to face classes result in similar learning gains in standardized exams and in comparable scores on homework assignments as face to face classes (e.g. Colvin, Champaign, Liu, Zhou, Fredericks, \& Pritchard, 2014; Dubson, Johnsen, Lieberman, Olsen, \& Finkelstein, 2014). To the best of our knowledge, no previous research has examined the effects of participating in a MOOC on teachers' self-efficacy beliefs, attitudes and concerns relating to inclusion. With the spread of this new type of online learning, that is available free of charge to large groups of people worldwide, it is important to investigate how MOOCs can alter teachers' beliefs and attitudes and ultimately to educational practices.

In order to fill these gaps, our study addressed the following research questions: RQ1: How do attitudes to inclusion and self-efficacy beliefs and concerns regarding inclusive language teaching differ at the beginning and end of a massive open online learning course? RQ2: How is self-reported course participation related to post-course attitudes, self-efficacy beliefs and concerns about inclusion in language teaching?

RQ3: How are previous training and knowledge about dyslexia related to pre- and postcourse attitudes, self-efficacy beliefs and concerns about inclusion in language teaching? RQ4: How are teaching context, level of education and teaching experience related to preand post-course attitudes, self-efficacy beliefs and concerns about inclusion in language teaching? 


\section{Method}

Context of the course

The study took place within the framework of a MOOC on Dyslexia and Language Teaching. The course was primarily aimed at teachers of languages, including English as an additional/ foreign language and modern foreign languages. The course was intended for a highly international audience and in addition to the advertising campaign of the course provider (Anonymised), it was publicised to language teachers using mailing lists of teacher organizations, social media and newsletters all over the world. Its goals were to raise teachers' awareness of the nature of specific learning difficulties, with a particular focus on dyslexia. It also aimed to familiarise them with inclusive language teaching practices and specific language teaching approaches, tasks and techniques that can assist the language learning processes of dyslexic students. The MOOC was based on materials developed in the DysTEFL project (www.dystefl.eu) (for more details see Nijakowska \& Kormos, 2016; Nijakowska et al., 2013). These materials, which were piloted in five different European countries in face-to-face, blended and online learning modes, were adapted to the demands of the massive open online learning environment by the first author and were complemented with additional video lectures, task demonstrations, resources, discussion and practical applications tasks. The pedagogical model underlying the course was that of the language teacher as a reflective practitioner (Tanner \& Green, 1998; Wallace, 1991). On the course, the participants were encouraged to experiment with new learner-centred teaching methodologies, creatively adapt teaching methods, tasks and techniques to their contexts and reflect on the outcomes of their learning and teaching processes. Within the constraints of the instructional design features of the FutureLearn MOOC platform, the course took a task- 
based approach to teacher development using tasks to enhance learning and reflection (for a review see Samuda \& Bygate, 2008).

The mentored phase of the course took place over four weeks. Each week covered one module. The first module aimed to develop teachers' understanding of specific learning difficulties and their effect on learning additional languages. The second module focused on the principles and practice of inclusive language teaching and the use of educational technology. The third module was concerned with developing the vocabulary and grammar skills of dyslexic language learners and the last module concentrated on developing phonological and orthographic awareness and reading skills. Each module consisted of approximately 15 instructional steps. The completion of one module was expected to take four hours. Participants could complete the modules and steps at their own pace and also finish and revisit tasks after the four weeks of the mentored phase.

The instructional materials each week included video-lectures, teaching demonstrations, interviews with dyslexic students and expert researchers, readings in the form of book chapters and information sheets. Each of these 'input tasks' was usually preceded by questions to help their understanding, guide their reading/ viewing and draw and reflect on pre-existing knowledge. This was then followed up by discussion questions and reflection prompts. Other instructional tasks included forum discussions, designing pedagogical tasks, sharing them and giving feedback on tasks designed by peers on the course. Multiple choice quizzes with feedback and peer-assessment tasks were also used to assess participants' progress.

For the four weeks of the mentored phase of the course, a team of three educators and six mentors worked as mentors and facilitators. The mentors and facilitators encouraged discussion, gave feedback and assisted in answering questions and clearing up misunderstandings. Each day one mentor monitored and facilitated the course for eight hours. 


\section{Participants}

The course had 18,860 enrolled learners of which 9,706 were active learners, meaning that they engaged with at least one of the instructional steps. From among the active learners, 2,499 completed all the tasks and 4,770 were socially active. From these learners, 1,187 participants responded to our pre-course and 752 to our post-course surveys. Approximately $67 \%$ of the respondents were from European countries including the UK, $15 \%$ from America, $10 \%$ from Asia, 5\% from Australia and 3\% from Africa. Participants completing the pre- and post-course surveys could not be matched due to issues of confidentiality and anonymity. Therefore, the pre- and post-course survey participants are treated as separate groups and their characteristics are also reported separately.

In the pre-course survey, $92.8 \%$ of the respondents were female and $8.2 \%$ male, and in the post-course survey $88.2 \%$ were female and $11.8 \%$ male. Approximately equal proportions of teachers in the pre- and post-course surveys held undergraduate (pre-course: $41.43 \%$, post-course: $40.11 \%$ ) and postgraduate qualifications (pre-course: $38.71 \%$, postcourse: $41.9 \%$ ) The majority of the pre- and post-course survey participants taught English as an additional language and the second largest group of teachers taught modern foreign languages. Approximately $30 \%$ of the teachers in both surveys worked in secondary education and about a quarter of the respondents in both phases taught in the primary sector. Around $15 \%$ of the respondents in both surveys worked in higher education institutions. Over $50 \%$ of both pre- and post-survey participants had more than ten years' teaching experience and only around 5\% of the respondents had no teaching experience in either administration.

\section{Instrument}


The pre-course questionnaire contained 26 items and the post-course questionnaire consisted of 30 items (see Appendix 1 for the post-course questionnaire). Both versions of the questionnaire included ten background questions that asked about biographical information, teaching experience and prior training and experience in teaching students with dyslexia. The next 16 six-point Likert-scale items aimed to assess participants' attitudes to inclusive second language education ( 3 items), self-efficacy beliefs relating to the successful application of inclusive second language teaching approaches (6 items) and concerns about inclusion and the successful application of inclusive teaching practices ( 7 items). 8 items referring to attitudes (items 12, 13, and 19) and concerns (items 15, 17, 18, 21, and 25) were selected and adapted from the Sentiments, Attitudes, and Concerns about Inclusive Education Revised (SACIE-R) scale, which was originally designed for measuring pre-service teachers' perceptions about inclusion, more specifically their sentiments or comfort levels when engaging with people with disabilities, acceptance of learners with different needs, and concerns about implementing inclusion (Forlin, Earle, Loreman, \& Sharma, 2011). We also selected and adapted 4 items referring to efficacy to use inclusive instruction (items 16, 20, 23, and 26) from the Teacher Efficacy for Inclusive Practices (TEIP) scale (Park, Dimitrov, Das, \& Gichuru, 2016; Sharma, Loreman, \& Forlin, 2012). TEIP was originally designed to measure self efficacy to teach in inclusive classrooms and covered three areas of efficacy, namely, efficacy in using inclusive instruction, efficacy in collaboration with parents and other professionals, and efficacy in managing students' behaviour. The wording of the adapted items from both scales was slightly changed so that they referred to dyslexic students (rather than to a broader group of students with disabilities) and the second language learning/teaching context. Finally, we designed four additional items, two of them relating to self-efficacy (items 14 and 24) and two referring to concerns (22 and 27). We added four 
items to the post-course survey that were meant to give us insights into the extent to which respondents participated in the online course (e.g. percentage of tasks and number of modules they completed, the number of comments and replies posted online).

\section{Procedure}

The questionnaire was administered online using the SurveyMonkey tool. A link to the precourse questionnaire was sent to participants in an email that contained a welcome message and important joining and course information a week before the course start. The link was also embedded in the first instructional step of the FutureLearn interface. The link to the precourse questionnaire was active until the end of the first week of the course to allow those who were joining up to that point to access it. In the last week of the course we opened the link to the post-course survey, which then remained active on the SurveyMonkey platform for one week after the official end date of the mentored phase of the course. The link was sent to the participants in the weekly email, which gave them information about the last module of the course, and it was also embedded in the last instructional step of the MOOC.

\section{Analyses}

As a first step we carried out a principal component analysis of the attitude, self-efficacy and concern-related items in the pre- and post-course questionnaire data separately. The initial factor analysis revealed that two items in both versions of the questionnaire were not functioning as expected. This was because they either had a low overall factor loading or because they loaded on two factors with very similar factor loadings. We then removed these items from further analyses and reran the factor analysis for the pre- and post-course datasets. The Kaiser-Meyer-Olkin measure of sampling adequacy was .83 for the pre-test and .85 for the post-test, both of which values are well above the recommended minimum value of .50 
(Pett, Lackey \& Sullivan, 2003). A Barlett's test of sphericity reached statistical significance $(p<.001)$, supporting the factorability of the correlation matrix in both cases. Six selfefficacy items formed one factor with an Eigenvalue of 4.20 (28.04\% of the variance explained) in the pre-test and 4.57 (32.67\% of the variance explained) in the post-test. The five items relating to concerns constituted another factor with an Eigenvalue of $2.02(13.49 \%$ of the variance explained) in the pre-test and an Eigenvalue of 1.78 (12.65\% of the variance explained) in the post-test. The final attitude factor consisted of three items and had an Eigenvalue of 1.72 (11.50\% of the variance explained) in the pre-test and $1.38(9.91 \%$ of the variance explained) in the post-test (see Appendix 2 for the exact factor scores in both administration sessions). The reliability of the attitude (pre-course $\alpha=0.711$; post-course $\alpha=$ 0.676 ) and self-efficacy scales (pre-course $\alpha=0.820$, post-course $\alpha=0.828$ ) was high. The reliability values for concerns about the inclusion scale were somewhat lower but still within the acceptable range (pre-course $\alpha=0.665$; post-course $\alpha=0.688$ ). For further analysis, composite scores for each of the scales were created using regression factor scores (Tabachnick \& Fidell, 2001).

In order to answer our first research question we used multiple analysis of variance (MANOVA) and compared the pre- and post-course answers along the three scales relating to attitudes, self-efficacy beliefs and concerns. For the analysis of the three remaining research questions we performed a general linear model (GLM) analysis.

\section{Results}

In our first research question we asked how attitudes to inclusion, self-efficacy beliefs and concerns regarding inclusive language teaching differ at the beginning and end of the MOOC. In order to answer this question, we compared the means of the composite scores of the participants' answers to the attitude, self-efficacy and concerns scales in the pre- and post-course questionnaire by means of MANOVA. The mean composite scores were 
calculated as the average of the items on each scale. For this analysis, factor scores could not be used because they were centred around the mean. The analysis indicated a significant and large-size overall effect of the change in the composite scores of the scales, Wilks lambda $=$ $0.650, F(3,1566)=281.99, p<.001$, partial eta squared $=.350$. The results for the individual scales showed that post-course attitudes and self-efficacy beliefs were significantly higher and concerns significantly lower than at the beginning of the course. The effect size of the change was, however, small for attitudes and concerns and large only for self-efficacy beliefs (see Table 1).

Table 1. Differences between pre- and post-course attitudes, self-efficacy beliefs and concerns

\begin{tabular}{|c|c|c|c|c|c|c|c|}
\hline Scale & Time & $\mathrm{N}$ & Mean & $\mathrm{SD}$ & $\mathrm{F}$ & $\mathrm{p}$ & $\begin{array}{c}\text { partial } \\
\text { eta } \\
\text { squared }\end{array}$ \\
\hline \multirow[t]{2}{*}{ Attitudes } & Pre-course & 940 & 4.22 & .87 & 41.03 & .000 & .026 \\
\hline & Post-course & 630 & 4.49 & .77 & & & \\
\hline \multirow[t]{2}{*}{ Self-efficacy } & Pre-course & 940 & 3.65 & .88 & 840.39 & .000 & .349 \\
\hline & Post-course & 630 & 4.82 & .60 & & & \\
\hline \multirow[t]{2}{*}{ Concerns } & Pre-course & 940 & 1.05 & .80 & 35.64 & .000 & .022 \\
\hline & Post-course & 630 & 0.80 & .82 & & & \\
\hline
\end{tabular}


Our second research question looked at how self-reported course participation is related to post-course attitudes and concerns about inclusion and self-efficacy beliefs when teaching languages to students with dyslexia. We applied general linear model (GLM) analysis with the factor scores of the attitude, self-efficacy and concern scales as the dependent variables for each model and the percentage of tasks and number of units completed, the number of comments and replies posted online as the independent variables (for the description of the calculation of factor scores see the Analysis section). The model for the attitude scale showed no significant effect for any of the course participation variables, Chi-square $=26.81 p=.786 .{ }^{1}$ In contrast, the model for post-course self-efficacy proved to have a good fit, Chi-square $=61.09 p=.002$. Among the independent variables, it was the percentage of tasks completed that demonstrated a significant effect, Wald Chisquare $=39.04 p=.01$. A standardized Beta value showed that 18 percentage of variance in post-course self-efficacy beliefs was explained by the percentage of tasks completed. The model for concerns also indicated an overall effect for the course participation variables, Chisquare $=52.35 p=.017$. The number of replies posted was a significant predictor for the decrease in concerns, Wald Chi-square $=9.87 p=.043$. The results showed that the difference was significant $(p<.001)$ between those who posted no replies and those who posted $1-5$ replies.

We were also interested in what role previous training and knowledge about dyslexia played in pre- and post-course attitudes to inclusion, self-efficacy beliefs and concerns regarding inclusive language teaching (see RQ3). We applied general linear model (GLM) analysis with the factor scores of the attitude, self-efficacy and concern scales as the dependent variables for each model and three questionnaire items on previous training, experience of working with dyslexic students and knowledge of dyslexia as the independent variables. Neither the model for the pre-course attitude factor score, Chi-square $=9.63 p$ 
$=.141$, nor the post-course attitude factor score, Chi-square $=2.07 p=.355$, showed any significant effect for the independent variables. The model for pre-course concerns, however, revealed a significant overall effect, Chi-square $=43.52 p<.001$. Initial training was not significantly related to pre-course concerns, Wald Chi-square $=0.21 p=.884$, but participants with no previous experience of teaching dyslexic students, Wald Chi-square $=9.09 p=.003$, and less knowledge of dyslexia, Wald Chi-square $=21.04 p<.001$, were significantly more concerned about inclusive education (see Table 2). A post hoc Bonferroni test showed that those participants who reported poor knowledge of dyslexia voiced more concerns than those with average, good or very good self-reported knowledge of dyslexia $(\mathrm{p}<.01)$. Interestingly, the model for post-course concerns did not have a significant fit, indicating that by the time the students finished the course, previous experience, training and knowledge of dyslexia was no longer a significant factor in their concerns about inclusion, Chi-square $=4.29 p=.117$.

Table 2. Differences in pre-course concern factor scores according to previous training, experience and knowledge of dyslexia

\begin{tabular}{lcccccc}
\hline & Group & $\mathrm{N}$ & $\begin{array}{c}\text { Mean } \\
\text { factor } \\
\text { score }\end{array}$ & SD & $\begin{array}{c}\text { Wald } \\
\text { Chi- } \\
\text { square }\end{array}$ & $\mathrm{p}$ \\
\hline $\begin{array}{l}\text { Participation in initial } \\
\text { training/ professional }\end{array}$ & yes & 216 & -.003 & .22 & 0.210 & .884 \\
development & no & 806 & -.027 & .09 & & \\
Previous experience of & yes & 662 & .093 & .16 & 9.09 & .003 \\
teaching dyslexic students & no & 335 & -.124 & .17 & & \\
Knowledge of dyslexia & none & 19 & -.208 & .22 & 21.04 & .001 \\
& poor & 259 & -.253 & .07 & & \\
& average & 497 & -.006 & .05 & & \\
& good & 174 & .080 & .07 & & \\
& very good & 48 & .400 & .14 & & \\
\hline
\end{tabular}


The GLM analysis indicated that pre-course self-efficacy beliefs were very strongly associated with previous training, experience and knowledge of dyslexia, Chi-square $=362.81$ $p<.001$. Participants with no prior training, Wald Chi-square $=45.62 p<.001$, and no previous experience of working with dyslexic students, Wald Chi-square $=39.14 p<.001$, were significantly less confident about their ability to cater for the needs of dyslexic language learners in their classrooms. Self-reported knowledge of dyslexia was also a significant predictor of pre-course self-efficacy beliefs, Wald Chi-square $=167.28 p<.001$ (see Table 3).

Table 3. Differences in pre-course self-efficacy factor scores according to previous training, experience and knowledge of dyslexia

\begin{tabular}{lcccccc}
\hline & Group & $\mathrm{N}$ & $\begin{array}{l}\text { Mean } \\
\text { factor } \\
\text { score }\end{array}$ & SD & $\begin{array}{c}\text { Wald } \\
\text { Chi- } \\
\text { square }\end{array}$ & p \\
\hline $\begin{array}{l}\text { Participation in some initial } \\
\text { training/ professional }\end{array}$ & Yes & 206 & .325 & .07 & 45.62 &.$<.001$ \\
$\begin{array}{l}\text { development } \\
\text { No }\end{array}$ & 761 & -.144 & .05 & & \\
Previous experience of & Yes & 638 & .278 & .05 & 39.14 & $<.001$ \\
teaching dyslexic students & No & 329 & -.097 & .06 & & \\
Knowledge of dyslexia & none & 18 & -.707 & .19 & 167.28 & $<.001$ \\
& poor & 254 & -.371 & .06 & & \\
& average & 477 & .066 & .04 & & \\
& good & 171 & .603 & .06 & & \\
& very good & 47 & .860 & .12 & & \\
\hline
\end{tabular}

At the end of the course, the general linear model with the post-course self-efficacy factor score as the dependent variable and previous training, experience and knowledge of dyslexia as the predictor variables had a significant fit, Chi-square $=152.97 p<.001$. From among the predictor variables, the individual effect of previous training, Wald Chi-square $=2.51 p$ $=.113$, and experience of teaching dyslexic students, Wald Chi-square $=2.70 p=.100$, were non-significant and only self-reported knowledge of dyslexia was significantly associated 
with self-confidence in implementing inclusive language teaching practices, Wald Chisquare $=144.73 p<.001$. The post hoc Bonferroni test showed that those participants who reported poor or average knowledge of dyslexia felt significantly less confident than those with good or very good self-reported knowledge of dyslexia $(\mathrm{p}<.001)$ (see Table 4). The difference between those with good and very good knowledge of dyslexia was also significant $(\mathrm{p}<.001)$.

Table 4 Differences in post-course self-efficacy beliefs according to reported knowledge of dyslexia

\begin{tabular}{|c|c|c|c|c|}
\hline Knowledge of dyslexia & $\begin{array}{l}\text { Comparisons with } \\
\text { other levels of } \\
\text { knowledge }\end{array}$ & $\begin{array}{c}\text { Mean } \\
\text { difference } \\
\text { in factor } \\
\text { scores }\end{array}$ & SD & $\mathrm{p}$ \\
\hline \multirow[t]{3}{*}{ Poor } & Average & -.213 & .16 & 1.000 \\
\hline & Good & -.805 & .16 & $<.001$ \\
\hline & Very Good & -1.459 & .17 & $<.001$ \\
\hline \multirow[t]{3}{*}{ Average } & Poor & .213 & .16 & 1.000 \\
\hline & Good & -.592 & .07 & $<.001$ \\
\hline & Very Good & -1.246 & .10 & $<.001$ \\
\hline \multirow[t]{2}{*}{ Good } & Poor & .805 & .16 & $<.001$ \\
\hline & Average & .592 & .07 & $<.001$ \\
\hline
\end{tabular}


In our fourth research question we addressed the role of teaching background in preand post-course attitudes and concerns relating to inclusive language teaching and teachers' self-efficacy beliefs in implementing inclusive teaching practices. In order to answer this question, we also carried out GLM analysis with the attitude, concern and self-efficacy scores as dependent variables and school type where teachers taught, the age group they taught, level of education and years of teaching experience as independent variables in the models. At the beginning of the course, the general linear model for attitudes to inclusion with the four independent variables had a significant fit, Chi-square $=28.56 p=.018$. From among the individual predictor variables, however, only the number of years of teaching experience reached a near significance level, Wald Chi-square $=7.76 p=.05$. The model for concerns regarding inclusive practices also had a significant fit, Chi-square $=26.23 p<.001$, but only the subjects teachers taught proved to be significantly associated with concerns, Wald Chisquare $=14.158 p=.007$. The post hoc analyses showed that teachers of English as an additional language were significantly more concerned than modern foreign language teachers $p=.012$.

The GLM analysis also revealed a good model fit for the role of teaching background variables in pre-course self-efficacy beliefs, Chi-square $=72.63 p<.001$. Significant predictor variables in the model were the school type where teachers work, Chi-square= $45.57 p<.001$, and the number of years of teaching experience, Chi-square $=13.88 p=.003$. The post hoc Bonferroni analysis indicated that teachers in primary education reported higher levels of self-confidence with regard to the successful use of inclusive techniques than teachers working in early childhood $(p=.01)$ and higher education $(p=.001)$. Special education teachers also had significantly higher self-efficacy beliefs than those working in 
early childhood $(p<.001)$, secondary $(p=.013)$ and higher education $(p<.001)$ (see Table 5). The pre-course self-efficacy beliefs of participants with more than 10 years of experience were significantly different from those between 5 and $10(p=.019)$ and less than 5 years $(p=$ .007) (see Table 6). By the end of the course, the influence of teaching background seems to have disappeared, as neither the model for attitude, Chi-square $=2.072 p=.355$, nor for concerns, Chi-square $=4.29 p=.117$, nor for self-efficacy Chi-square $=22.949 p=.061$ showed a significant fit.

Table 5 Differences in pre-course self-efficacy beliefs based on areas of education

\begin{tabular}{|c|c|c|c|c|}
\hline & $\begin{array}{l}\text { Comparisons with } \\
\text { other areas of } \\
\text { education }\end{array}$ & $\begin{array}{c}\text { Mean } \\
\text { difference } \\
\text { in factor } \\
\text { scores }\end{array}$ & SD & $\mathrm{p}$ \\
\hline \multirow[t]{4}{*}{$\begin{array}{l}\text { Early Childhood } \\
\text { Education }\end{array}$} & $\begin{array}{l}\text { Primary/Elementary } \\
\text { Education }\end{array}$ & -.726 & .21 & .010 \\
\hline & Secondary Education & -.539 & .21 & .163 \\
\hline & Special Education & -1.099 & .25 & .000 \\
\hline & Higher Education & -.320 & .21 & 1.000 \\
\hline \multirow{3}{*}{$\begin{array}{l}\text { Primary/Elementary } \\
\text { Education }\end{array}$} & Secondary Education & .187 & .08 & .372 \\
\hline & Special Education & -.373 & .16 & .421 \\
\hline & Higher Education & .406 & .09 & .001 \\
\hline \multirow[t]{2}{*}{ Secondary Education } & Special Education & -.560 & .16 & .013 \\
\hline & Higher Education & .218 & .09 & .351 \\
\hline Special Education & Higher Education & .779 & .17 & $<.001$ \\
\hline
\end{tabular}

Table 6 Differences in pre-course self-efficacy beliefs based on years of teaching experience

\begin{tabular}{|l|r|r|r|r|}
\hline & $\begin{array}{l}\text { Comparisons with } \\
\text { other groups }\end{array}$ & $\begin{array}{c}\text { Mean } \\
\text { difference } \\
\text { in factor } \\
\text { scores }\end{array}$ & SD & p \\
\hline No teaching experience & Less than 5 years & .090 & .16 & 1.000 \\
\hline
\end{tabular}




\begin{tabular}{|l|l|r|r|r|}
\hline & Between 5-10 years & .065 & .16 & 1.000 \\
\hline & More than 10 years & -.179 & .15 & 1.000 \\
\hline \multirow{2}{*}{$\begin{array}{l}\text { Less than 5 years of } \\
\text { teaching experience }\end{array}$} & Between 5-10 years & -.025 & .10 & 1.00 \\
\hline $\begin{array}{l}\text { Between 5-10 years of } \\
\text { teaching experience }\end{array}$ & More than 10 years & -.270 & .08 & .007 \\
\hline
\end{tabular}

\section{Discussion}

In our first research question we enquired about differences in concerns, attitudes and selfefficacy beliefs relating to inclusive language teaching practices at the beginning and end of the course. The results show that participants' attitudes were more positive, their selfconfidence higher and their concerns lower at the end of the MOOC than at the onset of the course. Previous research has demonstrated face-to-face pre-service teacher training courses on inclusion have a positive effect in terms of enhancing attitudes, raising teachers' selfefficacy beliefs and alleviating concerns with regard to inclusion (e.g. Carroll et al., 2003; Campbell et al., 2003; Lambe \& Bones, 2007; Peebles \& Mondaglio, 2014; Shade \& Stewart, 2001; Sharma et al., 2008; Sharma \& Nuttall, 2016; Stella, Forlin, \& Lan, 2007). The courses investigated in previous studies were quite intensive and conducted over at least ten weeks. The novelty of our study is that it shows that even a short course conducted entirely online can potentially result in in enhanced teachers' attitudes, self-efficacy beliefs and decreased level of anxieties at the end of the course. Our research is the first to demonstrate that these effects relate specifically to the teaching of additional languages. The findings are remarkable because, unlike in blended learning and other traditional online teacher training courses, participants received minimal individual feedback from tutors, given the large number of enrolled students. Participants primarily learned by interacting with instructional tasks and with each other, although mentors did monitor the discussion forums. Peer scaffolding and 
participation in an online community of learners might have had a positive impact on the participants' self-efficacy beliefs, attitudes and concerns.

Kissau's (2012) study found that a significant drawback of online language teacher training courses is the lack of opportunities to observe examples of successful language teaching strategies, which in turn might negatively impact on the development of language teachers' self-efficacy beliefs. The course in our study, however, included videos of teaching demonstrations, which might have assisted the participants to raise their confidence in being able to apply inclusive language teaching practices in their own classrooms. Overall, the results indicate that upon the completion of the MOOC participants' self-efficacy beliefs were high, which is one the most important antecedents to the successful implementation of inclusive practices (Forlin, Jobling, \& Carroll, 2001; Forlin, Loreman et al., 2014). Increased self-efficacy beliefs give teachers the confidence to apply more inclusive teaching techniques, and these mastery experiences can, in turn, further enhance their self-efficacy (Tschannen-Moran, Woolfolk Hoy, \& Hoy, 1998; Tschannen-Moran \& Woolfolk Hoy, 2007). Future research would be needed to investigate if these increased self-efficacy beliefs lead to changes in inclusive practices in the classroom.

Nonetheless, it should be noted that the differences in participants' attitudes and concerns relating to inclusive language teaching practices had only a small effect size. One possible reason for the relatively small effect is the fact that the initial attitudes of the participants were quite positive (Mean $=4.22$ on a five-point scale), and they did not have very high level of concerns either (Mean $=1.05$ on a five point scale, where 1 indicates least concerned). An analysis of the characteristics of the participants revealed that although only $20 \%$ of them participated in any prior training relating to dyslexia, almost two-thirds of them had experience of teaching dyslexic language learners. These experiences might account for the initially positive attitudes and relatively low level of concerns. The results pertaining to 
our third and fourth research questions also suggest that attitudes to inclusion were unequivocally positive among the participants, regardless of previous experience, training and teaching background. The findings with regard to the small decrease in concerns may, however, indicate that a MOOC might not provide enough opportunities for teachers to gain reassurance relating to their anxieties. The short nature of the course might not have allowed teachers to experiment with techniques they learned during the course in their classrooms, and therefore they might have still remained slightly anxious about how inclusive practices could work in their own contexts.

Our results with regard to the relationship between self-reported course participation and post-course attitudes, concerns and self-efficacy beliefs (RQ2) suggest that participants who completed a larger proportion of tasks on the course demonstrated higher selfconfidence and those who posted more comments had lower levels of anxiety relating to inclusive language teaching practices. One must, however, be careful when interpreting these findings, as GLM gives information about the association between variables, it does not provide evidence for causality. This is especially true for the results concerning anxiety. The explanation that those who had fewer concerns about inclusion were more active in the discussion forums might be just as viable as the assumption that active participation contributed to a decrease in anxiety. It is possible to speculate, however, that the more tasks learners completed, the more they learned about the nature of dyslexia and its effects on language learning and the better understanding they had of how they can make their language classes more inclusive. This increased knowledge, then, might have alleviated some of their concerns.

In our third research question we investigated what role previous training and knowledge about dyslexia played in pre- and post-course attitudes to inclusion, self-efficacy beliefs and concerns regarding inclusive language teaching. In contrast with previous 
research (Forlin, Loreman \& Sharma, 2014; Sharma, Forlin, \& Loreman 2008), we found that these factors did not predict either pre- or post-course attitudes to inclusion. One possible reason for this discrepancy might be that as the pre-course survey shows, our participants already held positive attitudes when they enrolled on the course. The results with regard to pre-course self-efficacy beliefs confirm the findings of earlier studies which indicated that existing experience of teaching students with disabilities increases teachers' self-efficacy beliefs (Giallo \& Little, 2003; Malinen et. al, 2013). Participation in pre- or in-service teacher education and existing knowledge of dyslexia were also found to have a positively related to pre-course self-efficacy beliefs. These findings are similar to those of Sharma and Nuttal (2016) and Sharma and Sokal (2015) and reinforce the high importance of mastery experiences in the formation of self-efficacy beliefs. Previous studies have also highlighted that knowledge of successful reading intervention programmes and their underlying theoretical principles (e.g. Brady et al., 2009; McCutchen \& Berninger, 1999; McCutchen et al., 2002a, 2002b; McCutchen et al., 2009; Podhajski et al., 2009) serve as an important foundation for teachers' self-confidence. Pre-course concerns showed a similar pattern of relationships, with the exception of a lack of effect of prior training on dyslexia.

We were also interested in learning about the relationship between pre-course attitudes, concerns and self-efficacy beliefs and demographic variables, such as the type of school teachers work in, the age group they teach and the length of their teaching experience (see RQ4). Attitudes to inclusion before the course were not found to be strongly associated with any of the demographic factors, which we might explain by making reference to the participants' already existing positive attitudes demonstrated in the pre-course survey. Concerns about inclusion at the beginning of the course, however, differed depending on whether the teachers taught English as an additional language (EAL) or modern foreign languages (MFL). This difference might be explained by the fact that in many contexts where 
our respondents teach, English is a compulsory foreign language, and sufficient level of competence in English is often necessary for securing jobs and gaining access to further education opportunities. The high expectations for student achievement might put teachers of English as a foreign language under pressure and cause concerns about their abilities to meet their students' needs. Our sample of English teachers also included those who taught English as an additional language in target language contexts (e.g. the UK). The identification of learning difficulties in multilingual students is a complex process, as issues relating to language proficiency need to be differentiated from learning difficulties (Smith, 2013). These EAL teachers are under pressure to assist students as quickly and efficiently as possible so that their academic performance in the various other subject areas is not adversely affected. Moreover, in many contexts, resources for EAL education are limited (Zimmerman, 2010), which places an additional burden on teachers. In contrast, modern foreign languages occupy a less central role in the curriculum in the UK, where most of our participants who taught MFL came from, and are often seen as optional subjects. Therefore, MFL teachers might have been less concerned about their skills and ability to include students with dyslexia in their classes.

Teachers working in primary education and special education teachers were found to have significantly higher self-efficacy beliefs at the beginning of the course than early childhood and lecturers in higher education. Secondary school teachers also reported lower levels of self-efficacy than special education teachers. The finding that special education teachers' self-efficacy beliefs are high is not surprising, given the fact that they have theoretical knowledge, adequate training and experience with inclusive practices. Primary school teachers are more likely to have substantial experience of teaching dyslexic children compared to those working in higher education, which might account for their enhanced selfefficacy beliefs. Early childhood educators' self-confidence might be low as learning 
difficulties are not identified at such a young age, and so these teachers might not be able to recognize students who are at risk of learning difficulties.

The effectiveness of the MOOC also manifested itself in the results that showed that, by the end of the course, none of the demographic variables were significantly associated with self-efficacy beliefs, attitudes and concerns about inclusive language teaching practices (RQ4). Another encouraging finding was that neither post-course concerns nor attitudes were influenced by prior training and experience or existing knowledge about dyslexia (RQ3). Knowledge of dyslexia, however, remained a significant predictor of post-course selfefficacy beliefs. At the end of the course, $5 \%$ of the participants still reported poor knowledge of dyslexia and a third of the respondents evaluated their knowledge of dyslexia as being at an 'average' level. These participants' post-course self-efficacy beliefs were significantly lower than those who judged their knowledge to be 'good' or 'very good'. These results suggest that the course might have been too short and not all participants benefitted from the autonomous learning environment of the MOOC.

\section{Conclusions and implications}

This study makes an important contribution to knowledge on teacher attitudes, concerns and self-efficacy beliefs about implementing inclusive practices in the context of second language teaching. Using an online survey instrument, we demonstrated that, after taking part in a MOOC on dyslexia and language teaching, participants' attitudes and self-efficacy beliefs were higher and their concerns about implementing inclusive language teaching practices decreased. The outcomes of the study show that participants' demographic variables, such as type of school where teachers taught, age group they taught and length of their teaching experience, were not significantly related to post-course attitudes, self-efficacy beliefs or concerns about inclusive language teaching practices. Moreover, neither previous training nor 
self-perceived existing knowledge about dyslexia predicted either pre- or post-course attitudes to inclusion, while these factors, along with existing experience in teaching dyslexic students, positively influenced teachers' pre-course self-efficacy beliefs. Importantly, prior training, experience and existing knowledge about dyslexia had no impact on post-course concerns. Those who completed more tasks on the course were found to show increased postcourse self-efficacy beliefs and those who posted more comments demonstrated lower levels of anxiety relating to the implementation of inclusive practices.

The study has important implications for educational stakeholders with regard to language teacher training. The fact that the MOOC hosted a massive number of participants confirms the high demand for such training (in terms of course content, pedagogy and mode of delivery) among pre- and in-service language teachers. Our research demonstrates that a relatively short course run entirely online, during which participants become members of an online community of learners, can be successful in raising attitudes and self-efficacy beliefs and diminishing concerns about inclusion. These findings clearly justify the recommendation that such courses should be incorporated into pre- and in-service language teacher training. The fact that course participants were exposed to neither social contact nor teaching experience with students with dyslexia or other types of learning difficulties might be considered a drawback of the MOOC. This was, however, compensated for by the video recordings of individuals with dyslexia telling stories of their experiences of learning additional languages, as well as teachers in action demonstrating the techniques the course participants were learning about. In the online discussions, many course participants shared their prior experiences of working with learners with SpLDs and, most importantly, a number of teachers also reported how they were adapting what they had learnt during the course and how their learners were reacting to these changes. 
An important shortcoming of our research is that, due to the nature of the online survey, it was not possible to match participants' pre- and post-course responses and the data had to be considered as relating to two separate cohorts. Although the results indicate differences between the pre- and post-course variables, a matched design would have provided more evidence for the development of attitudes, concerns and self-efficacy beliefs. Further research that overcomes this limitation might add weight to our results. The questionnaire applied was also very short. A more detailed and longer instrument might yield additional insights into specific aspects of self-efficacy beliefs and anxieties of language teachers relating to inclusive practices. Interviews and diary data might also complement the quantitative findings of this study and enrich our understanding of the benefits and shortcomings of MOOCs in language teacher education. Further research is also needed regarding self-reported or intended and, in particular, actual instructional practices and classroom behaviours of language teachers following their participation in different types of training programmes on inclusive education.

\section{Notes}

1. In GLM analysis model fit is evaluated by testing the significance of the Chi-square value.

\section{References}

Ahmmed, M., Sharma, U., \& Deppeler, J. (2012). Variables affecting teachers' attitudes towards inclusive education in Bangladesh. Journal of Research in Special Educational, Needs 12, 132-140.

Avramidis, E., \& Norwich, B. (2002). Teachers' attitudes towards integration/inclusion: A review of the literature. European Journal of Special Needs Education, 17, 129-147. 
Bandura, A. (1977). Self-efficacy: Toward a unifying theory of behavioral change. Psychological Review 84, 191-215.

Bos, C., Mather, N., Dickson, S., Podhajski, B., \& Chard, D. (2001). Perceptions and knowledge of preservice and inservice educators about early reading instruction. Annals of Dyslexia, 51, 97-120.

Brady, S., Gillis, M., Smith, T., Lavalette, M., Liss-Bronstein, L., Lowe, E., North, W., Russo E., \& Wilder, T.D. (2009). First grade teachers' knowledge of phonological awareness and code concepts: Examining gains from an intensive form of professional development and corresponding teacher attitudes. Reading and Writing: An Interdisciplinary Journal, 4, 425-455.

Carroll, A., Forlin, C., \& Jobling, A. (2003). The impact of teacher training in special education on the attitudes of Australian pre-service general educators toward people with disabilities. Teacher Education Quarterly, 30, 65-79.

Campbell, J., Gilmore, L., \& Cuskelly, M. (2003). Changing student teachers' attitudes towards disability and inclusion. Journal of Intellectual \& Developmental Disability, 28, 369379.

Chao, C.N.G., Forlin, C., \& Ho, F.C. (2016). Improving teaching self-efficacy for teachers in inclusive classrooms in Hong Kong. International Journal of Inclusive Education, 20, $1142-1154$.

Colvin, K. F., Champaign, J., Liu, A., Zhou, Q., Fredericks, C., \& Pritchard, D. E. (2014). Learning in an introductory physics MOOC: All cohorts learn equally, including an oncampus class. The International Review of Research in Open and Distributed Learning, $15,263-283$.

Commonwealth Government of Australia (1992). Disability Discrimination Act. Canberra, Australia: Author. 
Dubson, M., Johnsen, E., Lieberman, D., Olsen, J., \& Finkelstein, N. D. (2014). Apples vs. oranges: Comparison of student performance in a MOOC vs. a brick-and-mortar ourse. Retrieved from http://www.compadre.org/per/items/detail.cfm?ID=13512

DysTEFL (2012). Needs analysis report. Retrieved from http://dystefl.eu/uploads/media/DysTEFL-Needs_analysis_report_01.pdf

DysTEFL and DysTEFL2 (nd). Retrieved from www.dystefl.eu

Forlin, C., \& Chambers, D. (2011). Teacher preparation for inclusive education: Increasing knowledge but raising concerns. Asia-Pacific Journal of Teacher Education, 39, 1732.

Forlin, C., \& Cooper, P. (2013). Student behaviour and emotional challenges for teachers and parents in Hong Kong. British Journal of Special Education, 40, 58-64.

Forlin, C., Earle, C., Loreman, T., \& Sharma, U. (2011). The Sentiments, Attitudes, and Concerns about Inclusive Education Revised (SACIE-R) Scale for measuring preservice teachers' perceptions about inclusion. Exceptionality Education International, $21,50-65$.

Forlin, C., Hattie, J. \& Douglas, G. (1996). Inclusion: Is it stressful for teachers? Journal of Intellectual \& Developmental Disability, 21, 199-217.

Forlin, C., Jobling, A., \& Carroll, A. (2001). Pre-service teachers' discomfort levels toward people with disabilities. Journal of International Special Needs Education, 4, 32-38.

Forlin, C., Loreman, T., \& Sharma, U. (2014). A system-wide professional learning approach about inclusion for teachers in Hong Kong. Asia-Pacific Journal of Teacher Education, 42, 247-260.

Forlin, C., Sharma, U., \& Loreman, T. (2014). Predictors of improved teaching efficacy following basic training for inclusion in Hong Kong. International Journal of Inclusive Education, 18, 718-730. 
Giallo, R., \& Little, E. (2003). Classroom behaviour problems: The relationship between preparedness, classroom experiences, and self-efficacy in graduate and student teachers. Australian Journal of Educational and Developmental Psychology, 3, 21-34.

Glance, D. G., Forsey, M., \& Riley, M. (2013). The pedagogical foundations of massive open online courses. First Monday, 18(5). Retrieved from http://firstmonday.org/article/view/4350/3673

Goldfus, C. (2012). Knowledge foundations for beginning reading teachers in EFL. Annals of Dyslexia, 62, 204-221.

Guàrdia, L., Maina, M., \& Sangrà, A. (2013). MOOC design principles: A pedagogical approach from the learner's perspective. eLearning Papers, 33, 1-6.

Horne, P., \& Timmons, V. (2009). Making it work: Teachers' perspectives on inclusion. International Journal of Inclusive Education, 13, 273-86.

Jang, S. (2008). The effects of integrating technology, observation and writing into teacher education method course. Computers \& Education, 50, 853-865.

Jordan, A, Schwartz, E., \& McGhie-Richmond, D. (2009). Preparing teachers for inclusive classrooms. Teaching and Teacher Education, 25, 535-542.

Joshi, R.M., Binks, E., Graham, L., Dean, E., Smith, D., \& Boulware-Gooden, R. (2009a). Do textbooks used in university reading education courses conform to the instructional recommendations of the National Reading Panel? Journal of Learning Disabilities, 42, $458-463$.

Joshi, R.M., Binks, E., Hougen, M., Dahlgren, M., Dean E., \& Smith, D. (2009b). Why elementary teachers might be inadequately prepared to teach reading. Journal of Learning Disabilities, 42, 392-402.

Kirtman, L. (2009) Online versus in-class courses: An examination of differences in learning outcomes. Issues in Teacher Education, 18, 103-116. 
Kissau, S. (2012). Perceptions of self-efficacy for two types of second language methods instruction. Computer Assisted Language Learning: An International Journal, 25, 295317.

Kissau, S., \& Algozzine, B. (2015). The impact of mode of instructional delivery on second language teacher self-efficacy. ReCALL, 27, 239-256.

Kormos, J. (2016). The second language learning processes of students with specific learning difficulties. New York: Routledge.

Kormos, J., \& Smith, A. M. (2011). Teaching languages to learners with specific learning difficulties. Clevedon: Multilingual Matters.

Lambe, J., \& Bones, R. (2007). The effect of school-based practice on student teachers' attitudes towards inclusion in Northern Ireland. Journal of Education for Teaching: International Research and Pedagogy, 33, 99-113.

Leyser, Y., Zeiger, T., \& Romi, S. (2011). Changes in self-efficacy of prospective special and general education teachers: Implication for inclusive education. International Journal of Disability, Development and Education, 58, 241-255,

Malinen, O-P., Savolainen, H., \& Xu, J. (2012). Beijing in-service teachers' self-efficacy and attitudes towards inclusive education. Teaching and Teacher Education, 28, 526-534.

Malinen, O-P., Savolainen, H., Engelbrecht, P., Xu, J., Nel, M., Nel, N., \& Tlale, D. (2013). Exploring teacher self-efficacy for inclusive practices in three diverse countries. Teaching and Teacher Education, 33, 34-44.

Martin, D. (Ed.). (2013). Researching dyslexia in multilingual settings: diverse perspectives. Bristol: Multilingual Matters.

McCutchen, D., \& Berninger, V.W. (1999). Those who know, teach well: Helping teachers master literacy-related subject-matter knowledge. Learning Disabilities Research \& Practice, 14, 215-226. 
McCutchen, D., Abbott, R.D., Green, L.B., Beretvas, S.N., Cox, S., Potter, N.S., Quiroga, T., \& Gray, A.L. (2002a). Beginning literacy: Links among teacher knowledge, teacher practice, and student learning. Journal of Learning Disabilities, 35, 69-86.

McCutchen, D., Dawn R.H., Cox, S., Sidman, S., Covill, A.E., \& Cunningham, A. (2002b). Reading teachers' knowledge of children's literature and English phonology. Annals of Dyslexia, 52, 207-228.

McCutchen, D., Green, L., Abbott, R.D., \& Sanders, E.A. (2009). Further evidence for teacher knowledge: Supporting struggling readers in grades three through five. Reading and Writing: An Interdisciplinary Journal, 22, 401-423.

Moats, L.C. (1994). The missing foundation in teacher education: Knowledge of the structure of spoken and written language. Annals of Dyslexia, 44, 81-101.

Moats, L.C. (2009). Knowledge foundations for teaching reading and spelling. Reading and Writing: An Interdisciplinary Journal, 22, 379-399.

Moats, L.C., \& Foorman, B.R. (2003). Measuring teachers' content knowledge of language and reading. Annals of Dyslexia, 53, 23-45.

Nijakowska, J. (2010). Dyslexia in the foreign language classroom (Vol. 51). Multilingual Matters.

Nijakowska, J. (2014). Dyslexia in the European EFL teacher training context. In Essential topics in applied linguistics and multilingualism (pp. 129-154). Springer International Publishing.

Nijakowska, J., \& Kormos, J. (2016). Foreign language teacher training on dyslexia. L. Peer, G. Reid (Eds.), Multilingualism, literacy and dyslexia: Breaking down barriers for educators (pp. 104-115). Routledge: London.

Nijakowska, J. Kormos, S. Hanusova, B. Jaroszewicz, B. Kálmos, A. Imrene Sarkadi, et al. DysTEFL - Dyslexia for teachers of English as a foreign language (2013). Trainer's 
Booklet. Trainee's Booklet. CD-Rom. Cham, Germany: Druck+Verlag Ernst Vögel $\mathrm{GmbH}$

Multilingualism, Literacy and Dyslexia: Breaking Down Barriers for Educators, 104.

Özder, H. (2011). Self-efficacy beliefs of novice teachers and their performance in the classroom. Australian Journal of Teacher Education, 36(5), 1-15.

Park, M-H., Dimitrov, D.M., Das, A., \& Gichuru, M. (2016). The teacher efficacy for inclusive practices (TEIP) scale: Dimensionality and factor structure. Journal of Research in Special Educational Needs, 16, 2-12.

Peebles, J.L., \& Mondaglio, S. (2014). The impact of direct experience on preservice teachers' self-efficacy for teaching in inclusive classrooms. International Journal of Inclusive Education, 18, 1321-1336.

Peer, L., \& G. Reid. (Eds.). (2016). Multilingualism, literacy and dyslexia: Breaking down barriers for educators. London and New York: Routledge.

Pett, M.A., Lackey, N.R., \& Sullivan, J.J. (2003). Making sense of factor analysis: The use of factor analysis for instrument development in health care research. Thousand Oaks, CA: Sage Publications, Inc.

Podhajski, B., Mather, N., Nathan, J., \& Sammons, J. (2009). Professional development in scientifically based reading instruction: Teacher knowledge and reading outcomes. Journal of Learning Disabilities, 42, 403-417.

Samuda, V., \& Bygate, M. (2008). Tasks in second language learning. Houndmills: Palgrave Macmillan.

Shade, R. A., \& Stewart, R. (2001). General education and special education preservice teachers' attitudes toward inclusion. Preventing School Failure: Alternative Education for Children and Youth, 46, 37-41. 
Sharma, U., \& Nuttal, A. (2016). The impact of training on pre-service teacher attitudes, concerns, and efficacy towards inclusion. Asia-Pacific Journal of Teacher Education, 44(2), 142-155.

Sharma, U., \& Sokal, L. (2015). The impact of a teacher education course on pre-service teachers' beliefs about inclusion: An international comparison. Journal of Research in Special Educational Needs, 15, 276-284.

Sharma, U., Forlin, C., \& Loreman, T. (2008). Impact of training on pre-service teachers' attitudes and concerns about inclusive education and sentiments about persons with disabilities. Disability and Society, 23, 773-785.

Sharma, U., Forlin, C., Loreman, T. \& Earle, T. (2006). Pre-service teachers' attitudes, concerns, and sentiments about inclusive education: An international comparison of novice pre-service teachers. International Journal of Special Education, 21, 80-93.

Sharma, U., Loreman, T., \& Forlin, C. (2012). Measuring teacher efficacy to implement inclusive practices. Journal of Research in Special Educational Needs, 12, 12-21.

Schneider, E., \& Crombie, M. (2003). Dyslexia and foreign language learning. London: David Fulton Publishers.

Smith, A-M. (2013). Developing cognitive assessments for multilingual learners. In D. Tsagari \& G. Spanoudis (Eds.), Assessing L2 students with learning and other disabilities (pp. 151-168). Newcastle upon Tyne, UK: Cambridge Scholars.

Sparks, R., Ganschow, L., \& Pohlman, J. (1989). Linguistic coding deficits in foreign language learners. Annals of Dyslexia, 39, 179-195.

Sparks, R., Patton, J., Ganschow, L., Humbach, N., \& Javorsky, J. (2006). Native language predictions of foreign language proficiency and foreign language aptitude. Annals of Dyslexia 56, 129-160. 
Stella, C., Forlin, C., \& Lan, A. M. (2007). The influence of an inclusive education course on attitude change of pre-service secondary teachers in Hong Kong. Asia-Pacific Journal of Teacher Education, 35, 161-179.

Tabachnick, B.G., \& Fidell, L.S. (2001). Using multivariate statistics (4th ed.). Needham Heights, Mass.: Allyn and Bacon.

Takahashi, S. (2011). Co-constructing efficacy: A “communities of practice" perspective on teachers' efficacy beliefs. Teaching and Teacher Education, 27, 732-741.

Tanner, R., \& Green, C. (1998). Tasks for teacher education: A reflective approach. Harlow, UK: Addison Wesley Longman Publishing.

The National Archives, UK, (2015). The Equality Act, 2010. Retrieved from: http://www.legislation.gov.uk/ukpga/2010/15/contents

Tschannen-Moran, M., \& Hoy, A.W. (2001). Teacher efficacy: Capturing an elusive construct. Teaching and Teacher Education, 17, 783-805.

Tschannen-Moran, M., \& Woolfolk Hoy, A. (2007). The differential antecedents of selfefficacy beliefs of novice and experienced teachers. Teaching and Teacher Education 23, 944-956.

Tschannen-Moran, M., Woolfolk Hoy, A., \& Hoy, W. K. (1998). Teacher efficacy: Its meaning and measure. Review of Educational Research, 68, 202-248.

UNESCO (2015): Education For All 2000-2015: Achievements and challenges. Paris: UNESCO Publishing.

United Nations General Assembly (2006). Convention on the Rights of Persons with Disabilities. Retrieved from: http://www.un.org/esa/socdev/enable/rights/convtexte.htm

Wallace, M.J. (1991). Training foreign language teachers: A reflective approach. Cambridge: Cambridge University Press. 
Washburn, E.K., Joshi, R.M., \& Binks-Cantrell, E.S. (2011a). Teacher knowledge of basic language concepts and dyslexia. Dyslexia, 17, 165-183.

Washburn, E.K., Joshi, R.M., \& Binks-Cantrell, E.S. (2011b). Are preservice teachers prepared to teach struggling readers? Annals of Dyslexia, 61, 21-43.

Wilkins, T., \& Nietfeld, J.L. (2004). The effect of a school-wide inclusion training programme upon teachers' attitudes about inclusion. Journal of Research in Special Educational Needs, 4, 115-121.

Woodcock, S., Hemmings, B., \& Kay, R. (2012). Does study of an inclusive education subject influence pre-service teachers' concerns and self-efficacy about inclusion? Australian Journal of Teacher Education, 37(6), 1-11.

Zimmerman, L.W. (2010). ESL, EFL, and bilingual education: exploring historical, sociocultural, linguistic, and instructional foundations. Charlotte, North Carolina: Information Age Publishing. 


\section{Appendix 1: Perceptions about inclusive practices in teaching foreign languages to dyslexic language learners (FLIPD4) - post-course questionnaire}

1. Please read and tick all the statements below to proceed to the next page.

- I have read the information presented on this webpage relating to this project.

- I have understood the purposes of the project and what will be required of me. I agree to the arrangements described in the information section in so far as they relate to my participation.

- I understand that all data collected will be anonymous and confidential.

- By filling in this online questionnaire, I agree to participating in this research project.

2. My fulltime teaching job is in (Most of the time I teach in):

Early Childhood Education

Primary/Elementary Education

Secondary Education

Special Education

Higher Education

Not applicable

3. I am a teacher trainer:

Yes

No

4. I am:

Male

Female

5. My age is:

25 years or below

26-35 years

36-45 years

46 years or above

6. My highest level of education completed is:

Secondary School or its equivalent

Bachelor's Degree or its equivalent

Master's Degree

Other, please specify

\section{I have:}

No teaching experience

Less than 5 years of teaching experience

Between 5-10 years of teaching experience

More than 10 years of teaching experience

8. In my fulltime teaching job I teach (Most of the time I teach):

English as an additional language 
A modern foreign language other than English

English language and literature to first language speakers

Not applicable

Other subjects, please specify

9. Have you participated in any initial training or professional development sessions on teaching languages to dyslexic students before joining this MOOC?

Yes

No

10. I have experience working with/teaching students with dyslexia:

Yes

No

11. My knowledge of what dyslexia is:

None

Poor

Average

Good

Very Good

The following statements refer to inclusive practices towards dyslexic foreign language learners. Inclusive education involves students from diverse backgrounds and abilities learning with their peers in regular schools that adapt and change way they work in order to meet the needs of all.

\begin{tabular}{|c|c|c|c|c|c|c|}
\hline $\begin{array}{l}\text { Please indicate to what extent you agree with the } \\
\text { following statements. }\end{array}$ & 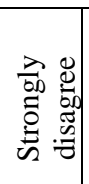 & 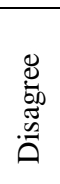 & 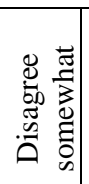 & 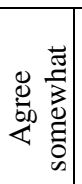 & 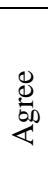 & \\
\hline $\begin{array}{l}\text { 12. Students who need an individualized academic } \\
\text { program should be encouraged to learn foreign/additional } \\
\text { languages. }\end{array}$ & & & & & & \\
\hline $\begin{array}{l}\text { 13. Students who frequently fail in various subjects should } \\
\text { be taught foreign/additional languages in mainstream } \\
\text { classes. }\end{array}$ & & & & & & \\
\hline $\begin{array}{l}\text { 14. I know how to create an inclusive atmosphere in the } \\
\text { language classroom for dyslexic learners. }\end{array}$ & & & & & & \\
\hline $\begin{array}{l}\text { 15. I am concerned that it will be/is difficult to give } \\
\text { appropriate attention to dyslexic students in my language } \\
\text { classes. }\end{array}$ & & & & & & \\
\hline $\begin{array}{l}\text { 16. I can use a variety of assessment strategies for } \\
\text { evaluating the foreign/additional language knowledge of } \\
\text { dyslexic students. }\end{array}$ & & & & & & \\
\hline $\begin{array}{l}\text { 17. I am concerned that my workload will increase if I } \\
\text { have dyslexic students in my language classes. }\end{array}$ & & & & & & \\
\hline
\end{tabular}




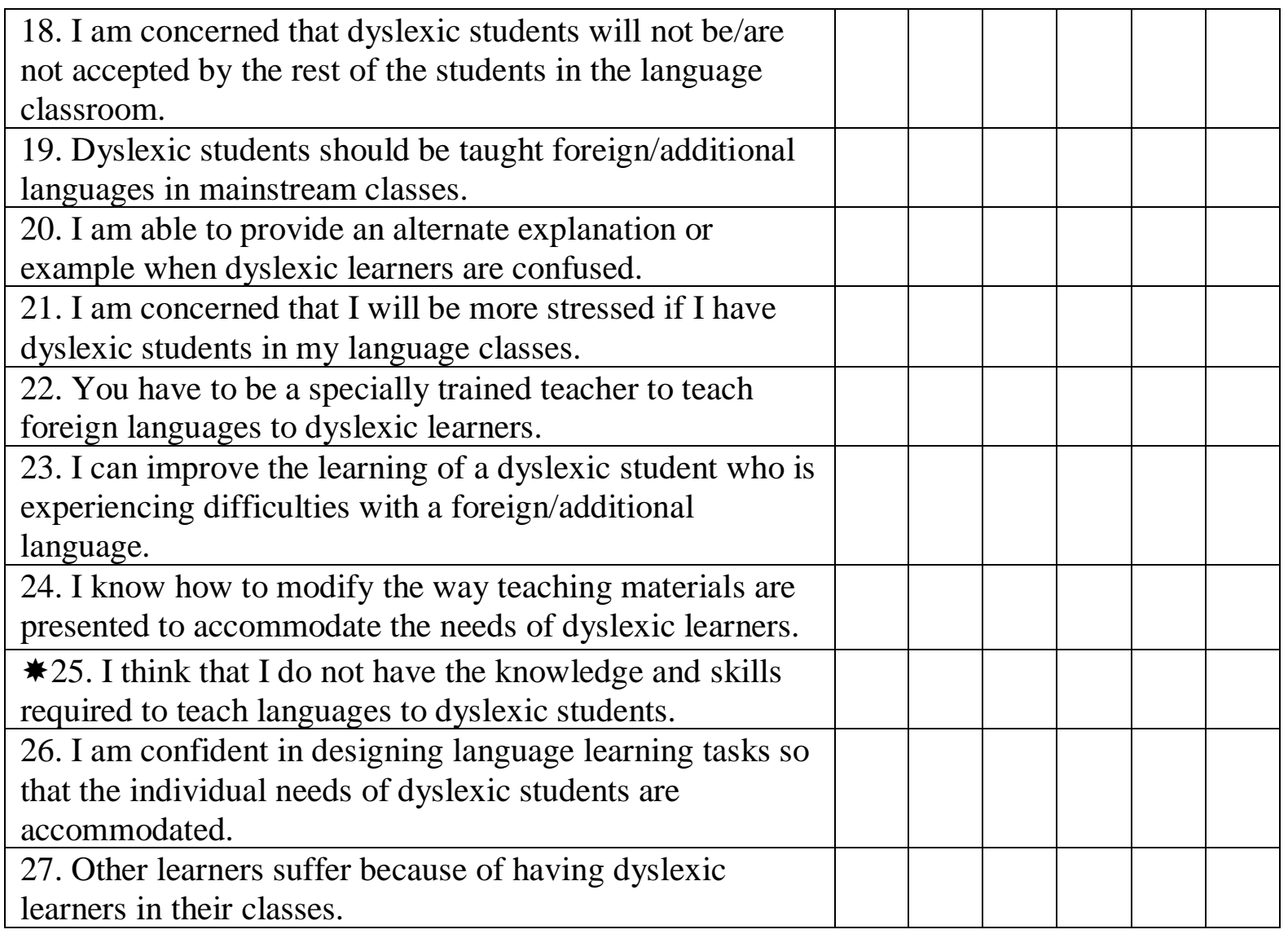

* items not included in the factor analysis because they showed no appropriate psychometric qualities.

\section{The following statements refer to your participation in this MOOC course.}

28. Approximately what percentage $(0 \%-100 \%)$ of the steps in the course did you complete? Please mark your answer in the box below.

29. How many of the units of the course did you participate in?

0
1
2
3
4

30. How many comments and answers did you post?

0

$1-5$

6-10

$11-15$

more than 15

31. How many times did you reply to someone else's post or comment?

0

$1-5$ 
6-10

11-15

more than 15 
Appendix 2 The factor loadings of the questionnaire items in the pre- and post-test

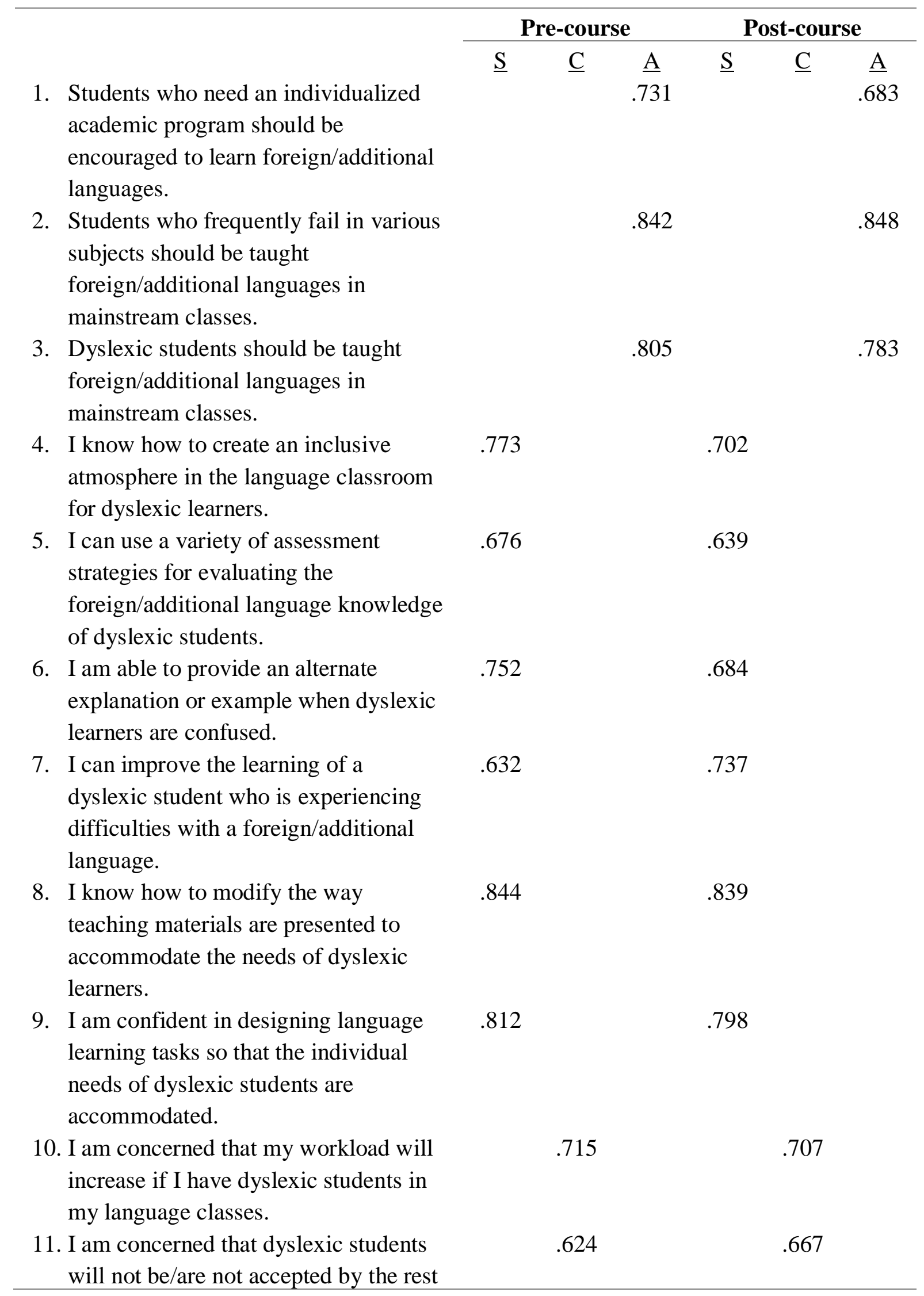


of the students in the language

classroom.

12. I am concerned that I will be more

.752

.741

stressed if I have dyslexic students in my language classes.

13. You have to be a specially trained

teacher to teach foreign languages to dyslexic learners.

14. Other learners suffer because of having dyslexic learners in their classes.

$\mathrm{S}=$ self-efficacy beliefs $\mathrm{C}=$ concerns $\mathrm{A}=$ attitudes 